\title{
PUBLIC SPACE AND THE EFFICIENCY OF THE NEW RESIDENTIAL ZONES IN SMALL SLOVAK TOWNS AND VILLAGES
}

\author{
Alžbeta Sopirová, Lucia Štefancová, Silvia Bašová, Karol Görner ${ }^{1}$
}

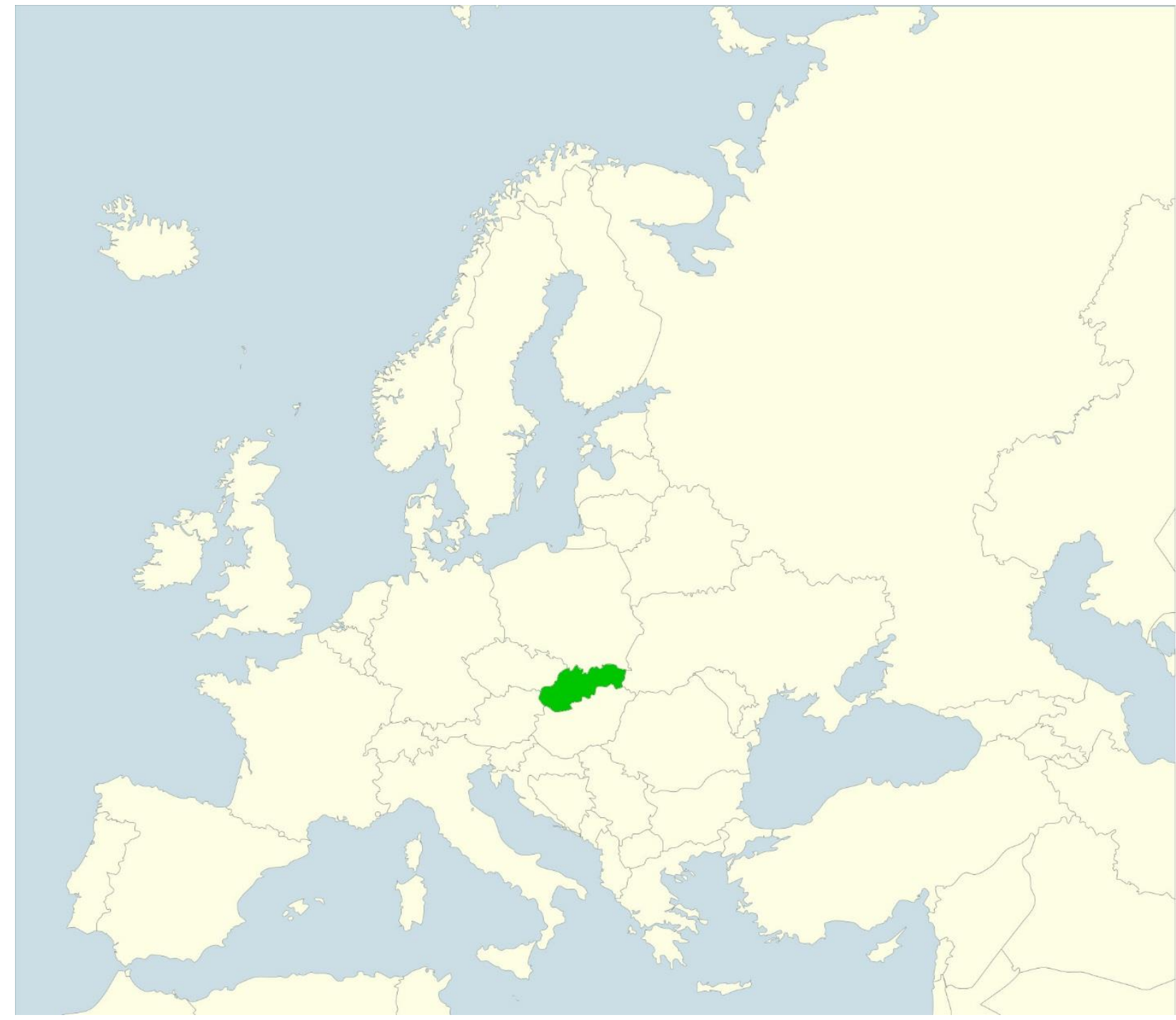

\footnotetext{
1 doc. Ing. arch. Alžbeta Sopirová, PhD., Ing. arch. Lucia Štefancová, PhD., doc. Ing. arch. Silvia Bašová, PhD. Ing. arch. Karol Görner, PhD., Institute of Urban Design and Planning, Faculty of Architecture, Slovak University of Technology Bratislava, Námestie slobody 19, 812 45, Bratislava, Slovakia; e-mails: sopirova@fa.stuba.sk, stefancova@fa.stuba.sk, basova@fa.stuba.sk,gorner@fa.stuba.sk
} 


\begin{abstract}
The paper deals with the issue of creation of new public spaces in emerging residential areas in rural settlements and small towns. The developers of the new residential zones currently pursue their private interests and the specific rural structure is complemented by isolated residential complexes without relation to the centre of the settlement and structure of the main public spaces. The hypothesis that the efficient residential structure can be achieved even at a higher percentage of active and vibrant public spaces is verified at eleven case studies in three selected settlements (Bernolákovo, Brezno, Chorvátsky Grob - Čierna Voda). The examined proposals (case studies) showed that despite the wide application of social and recreational public spaces and the large percentage of green area per capita, the site coverage coefficient was comparable and the population density was even higher than the current standards of development. In conclusion, it is possible to say, that the creation of public spaces in a residential zone does not adversely affect the efficiency of the new development. On the contrary, it brings a lot of benefits.
\end{abstract}

Key words: small towns, rural settlements, residential zone, public space, efficiency

Abstrakt: Článok sa zaoberá problematikou tvorby nových verejných priestorov novovznikajúcich obytných zón vo vidieckych sídlach a malých mestách. $V$ súčasnosti pri tvorbe nových obytných zón investori sledujú svoje privátne záujmy a špecifická vidiecka štruktúra je doplňaná o uzavreté a izolované obytné celky, bez vzájomnej väzby na centrum sídla a siet' nosných verejných priestorov. Cielom výskumu bolo overenie efektivity obytnej štruktúry s vyšším percentuálnym zastúpením aktívnych a živých verejných priestorov. Na 11 prípadových štúdiách v 3 skúmaných lokalitách obcí Bernolákovo, Brezno a Chorvátsky Grob - Čierna voda výskum overuje hypotézu, že aj pri koncentrovanejšej zástavbe je možné vytvorit' dostatok kvalitných spoločenských a rekreačných verejných priestorov a tým kvalitné a atraktívne bývanie. Napriek širokému uplatneniu spoločenských a rekreačných verejných priestorov a vysokému zastúpeniu zelene na obyvatel'a, skúmané štúdie vykazovali štandardné hodnoty koeficientu zastavanosti a nadštandardné hodnoty hustoty zal'udnenia v porovnaní so súčasnými trendami výstavby obytných zón. V závere možno konštatovat', že vytváranie verejných priestorov v obytnej zóne nemá nepriaznivý vplyv na efektivitu výstavby, naopak, prináša benefity do územia.

Kl'účové slová: malé mestá, vidiecke sídla, obytná zóna, verejný priestor, efektivita

\title{
1. Introduction
}

Suburbanisation is a phenomenon which has begun to manifest in Europe more significantly since the mid- $20^{\text {th }}$ century. The process of the population shift from the central urban areas of the cities to the outskirts respectively surrounding rural settlements brings many negative phenomena (reducing the concentration of population and social activities, increasing traffic demands, degradation of residential environment). In this way, the suburbanisation affects not only the life in the cities but also in rural areas.

Suburbanisation in Slovakia has appeared since the 1990s. A radical development of the new residential zones in Slovak rural areas in the last two decades is characterised by intensification of the existing built-up area as well as by untenable growth of the settlement into the surrounding agricultural landscape. The problem of the new residential development is not only the quantity but also the quality of the new housing environment.

Individual developers of the new residential zones pursue mainly their private interests. The specific rural structure is being complemented by closed and isolated residential complexes without having relationship to the centre of the settlement and key public spaces. Particularly, the mono-functional residential structures of monotonously lined up and often visually 
inconsistent single family houses with relatively high density and the almost total absence of social and recreational public spaces are preferred. The atmosphere and the vitality of the original rural settlement are disturbed which is accompanied by increasing anonymity and weakening of social relations. In terms of sustainability, the new developments represent inefficient solutions, contrary to current urban-architectural theories pointing to the importance of complex solutions with the presence of diversity and interconnection of the public spaces; however, the developers applying mostly economic criteria are not open to more complex solutions.

In this context, the fundamental question is: Can a complex residential area reflecting the current urban-architectural theories also be an efficient and attractive solution for developers?

The goal of the research was to verify the efficiency of a residential structure with the higher percentage of active and vibrant public spaces.

\section{Theoretical background}

The prerequisite for the development of the new urban structures in small towns and rural settlements is the knowledge of the laws of evolution of urban structure which teaches us about the compositional tasks for redevelopment, extension or urban proposal of the zone (Hruška, 1985). From the knowledge of the settlement, the possibilities for conceptual urban interventions and the new development plans can be derived. This allows preserving a certain developmental logic and the continuity of the development of the inner urban structure of the settlement, its readability and values created by previous generations. Context is always important: the continuity of urban structure, the character of traditional architecture and last but not the least, the search of relations and linkages between the original urban core, its central pole of social life and the new poles: micro-squares of new urban structures. The omission of this hierarchy causes a loss of orientation and identification with the (original) urban structure, disruption of natural continuity of development process in its functional and also mass-spatial nature, the creation of new urban structures with the character of independent islands without any relation to the original urban structure.

Gradual implementation of new functions and acceptable architectural forms to the settlement along with preservation of the original urban structure and functional coherence can create a rich and diverse environment that is in overall expression perceived as a valuable urban structure (Sopirová, 2011).

A lot of rural settlements and small towns in Slovakia have been affected in the last years by a construction activity represented by intensification of an existing built-up area or a large new development in greenfield lands. According to Vitková (2015), spatial development can generally be divided into 2 forms: the transformation of existing built-up areas and the development of the new areas. The rate of interventions into the original structure is often so severe that it completely disrupts the continuity of development and its character. One of the characteristic features of poor quality of suburban residential zones is definitely the absence of public spaces which are the place for meetings and important phenomenon for the quality of life in rural settlements (Czafík, Tóthová, 2016).

The image of the urban structure and its mass-spatial structure is being changed by the new residential development. The original scenery has been complemented by modern spatial dominants and accents which volume often exceeds the volume of the original urban structure (for example the formation of the new gateway to a town or a village represented by multi-storey apartment buildings). At the same time, the functional-operational structure and ownershiprelationship have been changed. The new structure of the streets often ignores the traffic relations between the original and the new urban structure. In order to achieve higher economic benefits, the high density and intensity of the new development presently come to fore. Mono-functional residential areas often arise as closed units without any agreement and a flexible coordination of individual developers in solving common construction activities.

The result of this development emerging under the pressure of lobby groups and pursuit for a quick profit are colonies of single family houses with low architectural quality and missing infrastructure. 
The basic requirements resulting from the economical land use and the efficient operation taken in account when creating the new residential environment include the higher intensity and multifunctionality of residential structure and associated minimisation of the transport flows. In pursuit of efficiency, the synergy of economy and the quality of living environment becomes a necessity (Vitková, 2008a).

The effort to adopt the new development to the original scale, searching for optimal functionaloperational relations to original urban structure and the sense of natural hierarchy, is absenting.

The public space is reduced to roads and pavements surrounded by monotonously ordered single-family houses along the simplified street. This causes the absence of public spaces and green areas. The next problem is isolation and insufficient connection of the public spaces due to the uncoordinated realisation of new residential developments (Kristiánová - Štěpánková, 2012). The effort to adapt to the original scale of the settlement, to search the optimal operational solutions and to create the functional and semantic differentiation of public spaces in the new urban structures is missing. This kind of development causes the loss of identity, historical and cultural continuity and violation of skylines, accents, orientation in space, specific architectural and urban footprint, material nature, scale, the internal and external image of the city and genius loci.

A man is trying to escape from the dynamic urban environment to quieter, and more natural rural environment which is paradoxically built without any rules or conception. The absence of some functions in the settlement causes adverse, daily transport (often tens of kilometres) to work, shops or leisure activities. The traffic congestion degrades the ability of the settlement to create a high-quality residential area (Hnilička, 2012).

Living in a single-family house by itself does not substitute the perception of the pleasant living environment. The quality of housing significantly depends on exterior spaces, especially public and semi-public spaces.

According to philosopher Martin Heidegger, the word "housing" is closely linked with the word "living". Housing represents the existential support for a man. A man is living and therefore also housing is not just in the intimacy of his house but also out in public in the company of other people (Glaeser - Kahn, 2004).

The value of the open space is not only philosophical, it reflects directly in the price of real estate. According to Geoghegan (2012), open spaces have a positive impact on the value of housing prices. This, in particular, refers to "permanent" open spaces with the guarantee of maintaining the current state. The results of this research are also confirmed by the study by Mc Connel, Walls (2005).

Despite the demand for public spaces is growing, public space is generally not the subject of a commercial market. This problem is addressed by Choumert (2010) on the example of green spaces, referring to the lack of satisfaction of citizens by the government (responsible public institutions).

From this point of view, it would be appropriate to legally anchor specific location of public spaces (including green spaces) already in the land use plans.

Pospěch et al. (2015) presented a sociological analysis of the image of a "good village", as portrayed in the annual Czech competition Village of the Year. The three most frequent categories (events, social relations and children) are all tied to the notion of everyday social life, as well as other frequently mentioned values, such as sports, culture, civil society and free time. Values, which are not related to everyday sociability (most notably, tradition and nature) have been mentioned often, yet not as often as the "social" ones. Importantly, the prevalence of the concept as well as the other frequently used categories (community, for children and others) draws a picture where a good village is an active village. It is, therefore, not an image of a peaceful, quiet village, but rather an image of a pulsing, lively and active place, which is represented in the pictures of successful applicants. The active life of the community can be located in public spaces. 
Public spaces are necessary not only in cities but also in rural settlements. They are usually represented by the historical core of the village but it is not enough. Together with the growth of the settlement, it is important to design the new local centres logically connected with the main core. These public spaces as the central poles of the urban life have the natural role of centralisation and intensification of urban structure and its population density. The density of builtup area and population density is increasing towards centres and decreasing in recreational areas. Disruption of above-mentioned patterns leads to anonymity and disintegration of social relations.

According to Kováč (2016), public spaces are one of the most important aspects of the culture of settlements. He highlights the missing legislative definition. The legislative documentation in the context of the development of rural settlements pays special attention to the functional use of public spaces. In the guidance of the Ministry of Transport and Construction of the Slovak Republic "Štandardy minimálnej vybavenosti obci" (The minimum standards of amenities of the settlements), in addition to the obligatory and recommended parameters, universal principles are also emphasised, such as the need for development of amenities and public spaces linked with recreational functions (Krumpolcová, 2009).

Contemporary small towns and rural settlements should take into account not only quantitative parameters but also qualitative aspects of public spaces (Figure 1). According to Jan Gehl (2012), public space must provide its users protection, comfort, enjoyment, smart places, relations and spirit of the space. Moreover, it is necessary to take into consideration the age of the visitors which reflects specific needs. The research of the term "rurality" showed that the most important factors of knowledge and the related subject of completing of the rural environment depend on scenarios of urban conception as well as on the direct experience of its inhabitants. According to McCormack (2002), the youngest social groups are an important indicator of the quality of the environment. Bruntlett (2014) highlights the importance of participation in the completion of the design of public spaces. Children, youth, families and seniors should have opportunities to benefit from specific public spaces. Multi-functional spaces of the squares of the rural settlements and small cities should be designed to invite all age groups (Bašová, 2016).

The ecological efficiency of the new residential zones in rural settlements and small towns should be achieved through the quality of the connection of urban and landscape conception. In this context, the green spaces have particular importance. The research of Mass et. al. $(2006$, p. 587) showed that, "percentage of green space in people's living environment has a positive association with the perceived general health of residents. Green space seems to be more than just a luxury and consequently, the development of green space should be allocated a more central position in spatial planning policy".

Contact with nature is particularly important in relation to school, square or playground. „Natural areas proximate to housing and schools are essential features in an effort to foster the resilience of children and perhaps, to promote their healthy development. Moreover, the fact that this result occurs within a rural context is particularly noteworthy" (Wells, Evans, 2003).

The European programs for reconstruction, a rural and an urban development like French program "BIMBY", German program "Dorferneuerung in Bayern, 2014" or Austrian programs „Niederösterrreich Dorferneuerung, 2016“ and "Schule der Dorferneuerung, 2016“ are also focused on the issue of completion and quality of public spaces. The emphases are on local identity, atmosphere and genius loci. Similar programs also took place in Slovakia. Jarábková et. al. (2016, p. 133) found out that, "in the previous period 2007-2015, the support of rural tourism in Slovakia (particularly Nitra Region) was mostly focused on support of investment activities of entrepreneurs (73\% of monitored sources). Significantly, lower volume of funds (only $4.3 \%$ ) was drawn for so-called soft projects. These projects aimed at organising events, revival of traditions in the area, marketing, creation of tourism products and promoting of cooperation." In an effort to revitalise the rural environment and the environment of small towns, we should not omit external economic factors influencing their development. As Heffner (2016) points out, there is a natural decline in the local economy of small towns and rural settlements in the sphere of the impact of bigger cities, and especially those that focus on tourism.

The consequence of this trend is also the decay of the urban structure. 


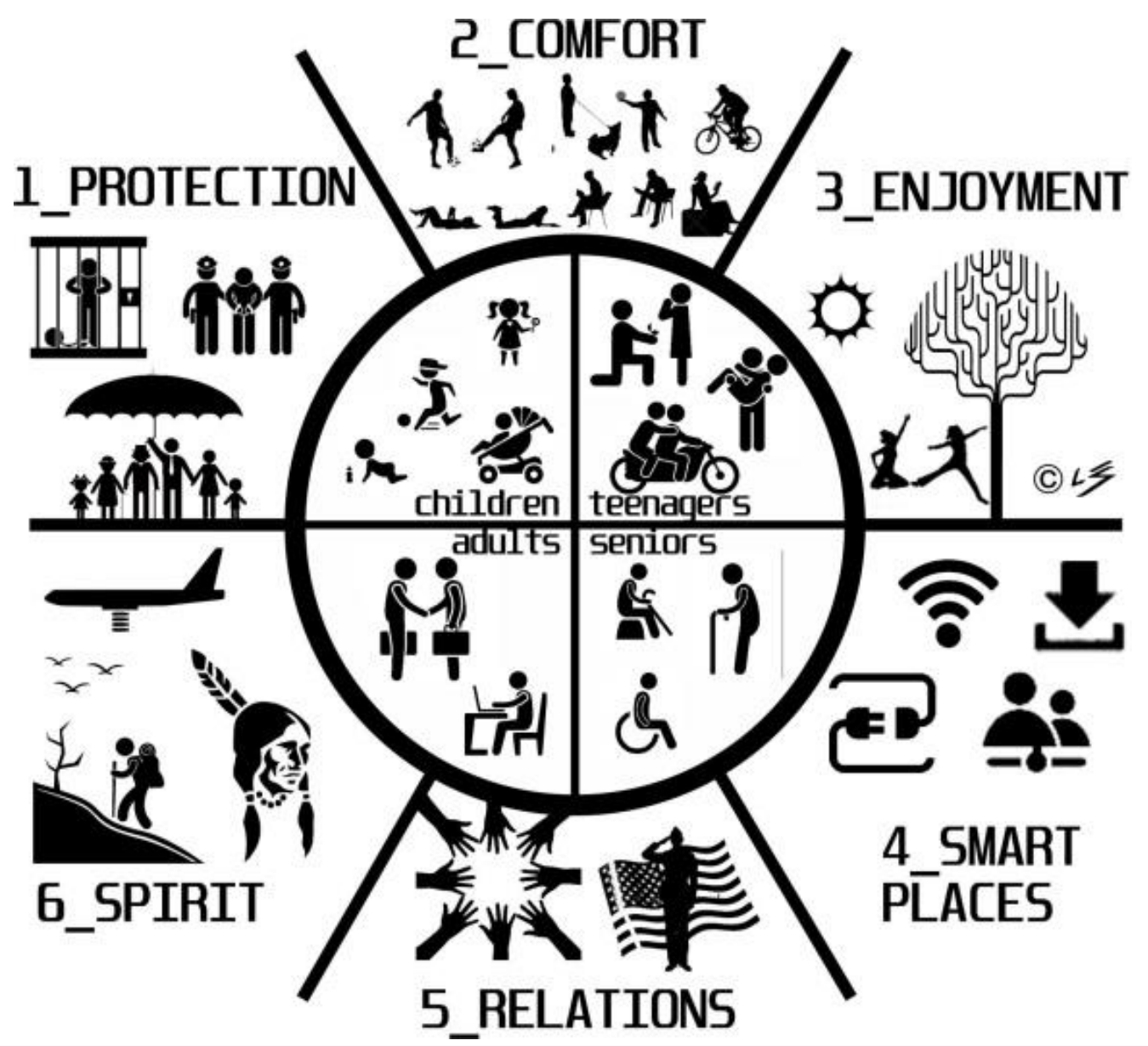

Fig 1. Qualitative aspects of public spaces (according to Gehl, 2012, p. 239). Author: L. Štefancová

\section{Methodology}

Research objectives: The goal of the research was to verify the efficiency of a residential structure with the higher percentage of active and vibrant public spaces.

Efficiency is in this paper understood primarily as an intensive use of the area in terms of the population densities of the selected area and its site coverage. The build-up area of the rural settlements and the current trends in residential development in these areas serve as a reference level for the assessment. Efficiently used areas are considered those areas which have similar or higher parameters of population density and site coverage than the current residential development.

Hypothesis: The efficient residential structure can be achieved even at a higher percentage of active and living public spaces.

\section{Phases and methods of research:}

PHASE 1: Selection of sites suitable for designing of public spaces in newly proposed residential zones of the settlements

Based on the cooperation with local authorities the research was applied in three settlements: Bernolákovo, Brezno, Chorvátsky Grob-Čierna Voda. The model sites for newly proposed residential zones were selected on the basis of their similar size, location and development plans of the settlement. This was important for a later comparison of selected quantitative and qualitative urban indicators. All locations represented developing situations in the open area (undeveloped or demolished) in touch with the original rural built-up area.

Applied methods: field research, interviews, assessment of available sources (maps, master plan of the settlement, literature) 
PHASE 2: Design of residential structures in selected locations

Variant concepts of newly proposed residential zones (in later phases of the research used as case studies) were made in 2016 as experimental student projects for municipalities. The student proposals reflected the real requirements of municipalities. They represent a spectrum of several different approaches in the design of public spaces, from an almost mono-functional residential area with a relatively small proportion of public space, through the structure with a predominance of commercial, social or sport and recreation public spaces, to a new urbanised district with a local centre.

Applied methods: Research by Design

PHASE 3: Assessment of quantitative and qualitative parameters of newly proposed residential zones

Quantitative parameters:

- Population Density (PD) = total amount of permanent residents (or expected residents by the proposals) / total land area; expressed in people per hectare (p./ha)

- Site coverage ratio $(\mathrm{SCR})=$ total built-up area / total area

- The proportion of greenery per person (PGI); expressed in square meters per person $\left(\mathrm{m}^{2} / \mathrm{p}\right.$.)

- Percentage of public spaces (PS) $=$ the share of social (SPS) and recreational (RPS) public spaces and the other spaces (OS) on the total open space of the residential zone

Qualitative parameters:

Assessment of the quality of proposed residential zones in terms of the presence of activities and functions in public spaces

Applied methods: quantitative (calculation of PD, SCR, PGI, PPS), qualitative (Assessment of the presence of activities and functions in proposed public spaces)

PHASE 4: Interpretation of results and recommendations for the design of new public spaces

Used methods: comparison, logical methods 


\section{Results and discussion}

\subsection{Description of selected settlements and localities}

For a better understanding of the research outcomes, it is necessary to understand the situation of the current state of the selected settlements (Figure 2).
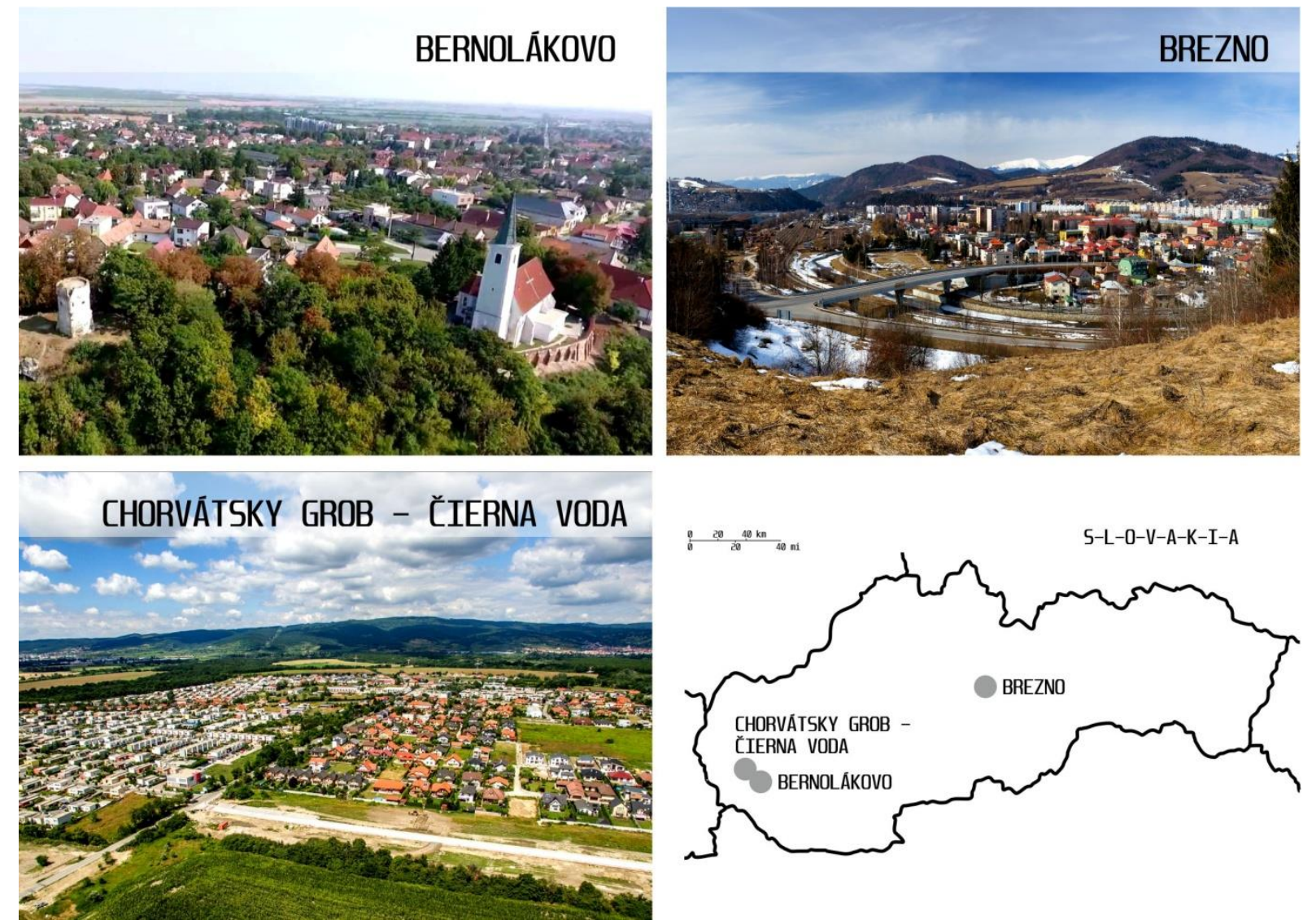

Fig 2. Panoramic views of Bernolákovo, Brezno, Chorvátsky Grob - part Čierna Voda and their localization in Slovakia. Source of photography: Bernolákovo https://i.ytimg.com/vi/hdh9/3gleoQ/maxresdefault.jpg Brezno - http://fotky.sme.sk/foto/265047/brezno-panorama, Čierna Voda - http: //www. kukucinova.sk/galeria/)

\section{Bernolákovo}

Bernolákovo is located in Bratislava agglomeration directly on the main development axes with the optimal accessibility of regional infrastructure. Since 1989, Bernolákovo became one of the suburbanisation cores. The population growth in the period 1991-2016 was $37.2 \%$ (Tab. 1). The original structure of the settlement has gradually changed by the new buildings and surrounded by new residential areas. The new zones on the outskirts of the village with a typical structure of single family houses or apartment houses of a new quality and building density are recording very dynamic development. The typical feature of these zones is a spatial segregation represented by a violation of historical land allocation and the formation of a new street structure ignoring existing relations to the original mass-spatial and functional-operational structure. The land allocation of the newly proposed residential developments on open areas represented by the simple additive sequencing of the same plots for the construction of single-family houses on both sides of the street, is marked by economic pragmatism. Mono-functioning of the new residential areas is underlined by the absence of basic amenities, public greenery, sport and recreational facilities. Uncertain socio-spatial identification is manifested by the lack of good quality and interconnectivity of public and semi-public spaces of various functional use and hierarchy. Spatial barriers in the form of separated, fenced, for public closed zones or unfinished streets with dead end roads and no connection to the surrounding, occur. These private zones reserved only for their residents are trying to substitute the lack of public spaces. The identity and originality of the village have been disappearing. The result is disruption of the natural 
cohabitation of the emerging and the indigenous communities. New residents, mainly represented by young and middle generation, have difficulties to assimilate with the local population. They often live "incognito" in their isolated world and they are not interested in the problems of the village and municipal politics.

\section{Brezno - locality "Barracks"}

Brezno is a small town located in central Slovakia surrounded by mountain ranges of Low Tatras and Veporské Rudohorie. It is an important gateway to the tourist destinations like Tále, Chopok or Čertovica. The town centre is formed by a rectangular square with a bell tower surrounded by the historical structure of townhouses. In recent years, the town had been growing mainly in westerly direction which is a natural result of its geographical location and historical realities. In the western part of the town, the amenities of citywide and regional importance such as shopping centres, ice stadium, bus station and hospital were built. These functions are surrounded by residential areas with an urban character in the southern part and rural character in the northern part of the town. Between these two functionally and structurally different parts, a complex of former army barracks, which have already been demolished was located. This unused area, considering its location, is a very attractive and potential space for transformation to the new local centre. This idea is also supported by the reduction of the transit traffic because of the construction of the traffic bypass of the town.

\section{Chorvátsky Grob - part Čierna Voda}

The village of Chorvátsky Grob is located approximately $20 \mathrm{~km}$ from the centre of Bratislava. It consists of two parts which have been developed since 1990 in a very different way. The old part of the village is stagnating while the new part called Čierna Voda, records a huge development of single family houses. The population growth of the village in the last 25 years was $238.32 \%$ (Tab. 1) (just official registered permanent residents were included). In 2001, the masterplan of the village was approved. From this time, it has already been changed 13 times but always just partially, without verification of the whole conception. The carelessness of the authorities who permitted the new development of large residential zones had nothing to do with conceptual urbanisation and public interest (neither current nor future residents).

Čierna Voda has become a characteristic suburb of Bratislava with undersized amenities, vital public spaces, sports areas, parks, traffic infrastructure and technical infrastructure. Developers ignored the needs and requirements of future residents. The traffic structure based on one main collecting communication serving the whole village, has reached its limits, causing the traffic collapses during the traffic peak. The indicated problems caused are that the real estates are gradually losing their value, even though there are still pressures from investors and individual subjects for new housing investments in this area.

Development of the new residential areas in the selected settlements is accompanied by a number of urban problems. These problems can be divided into several groups:

- spatial problems

- coexistence of the urban structure with the surrounding landscape of the village is hampered by penetration of new urban structure, changing the mass-spatial structure and architectural design, and causing irreversible changes to the landscape and silhouettes (skyline) of the village or town

- disruption of spatial relationships and linkages of the urban structure

- the absence of interconnected public spaces of different hierarchy

- functional problems

- quantitative and often also qualitative insufficient basic amenities - shops, schools, healthcare;

- the development of the new residential typologies with different quality and building density; 
- $\quad$ architectural problems

- construction of standardised catalogue of single family houses without relation to the local context;

- low quality and short lifecycle of the new buildings;

- operational problems

- the connection between the urban structure and the open land is degraded by the creation of barriers - enclosed and fenced residential complexes;

- the inability of the original urban structure to face the increasing demands for traffic and technical infrastructure, causing the necessity of new investments on public cost and a social tension in the area.

In order to design the residential zones serving as case studies for our research, the suitable localities in selected settlements were chosen. The student proposals were based on the characteristic features of the chosen localities.

- In Bernolákovo, the proposals benefit from a good location with a good pedestrian access to the urban core, the train station and the surrounding natural elements (river, greenery) (Figure 3). Moreover, "in terms of location of Bernolákovo in the urban area of the capital Bratislava, it is expected an expansion, an intensification of settlements, a growth of the urban character and its population" (Štefancová, 2016, p.109).

- In Brezno, the proposals focus on the creation of a new town centre which will connect the western and eastern part of the town, and at the same time create a new gateway to surrounding tourist destinations (Figure 4).

- In Chorvátsky Grob, the proposals concentrate on the creation of the missing centre of Čierna Voda in the area of the former agricultural cooperative which is largely demolished. The part of the preserved buildings was proposed to transform to the sport and the recreational function (Figure 5).

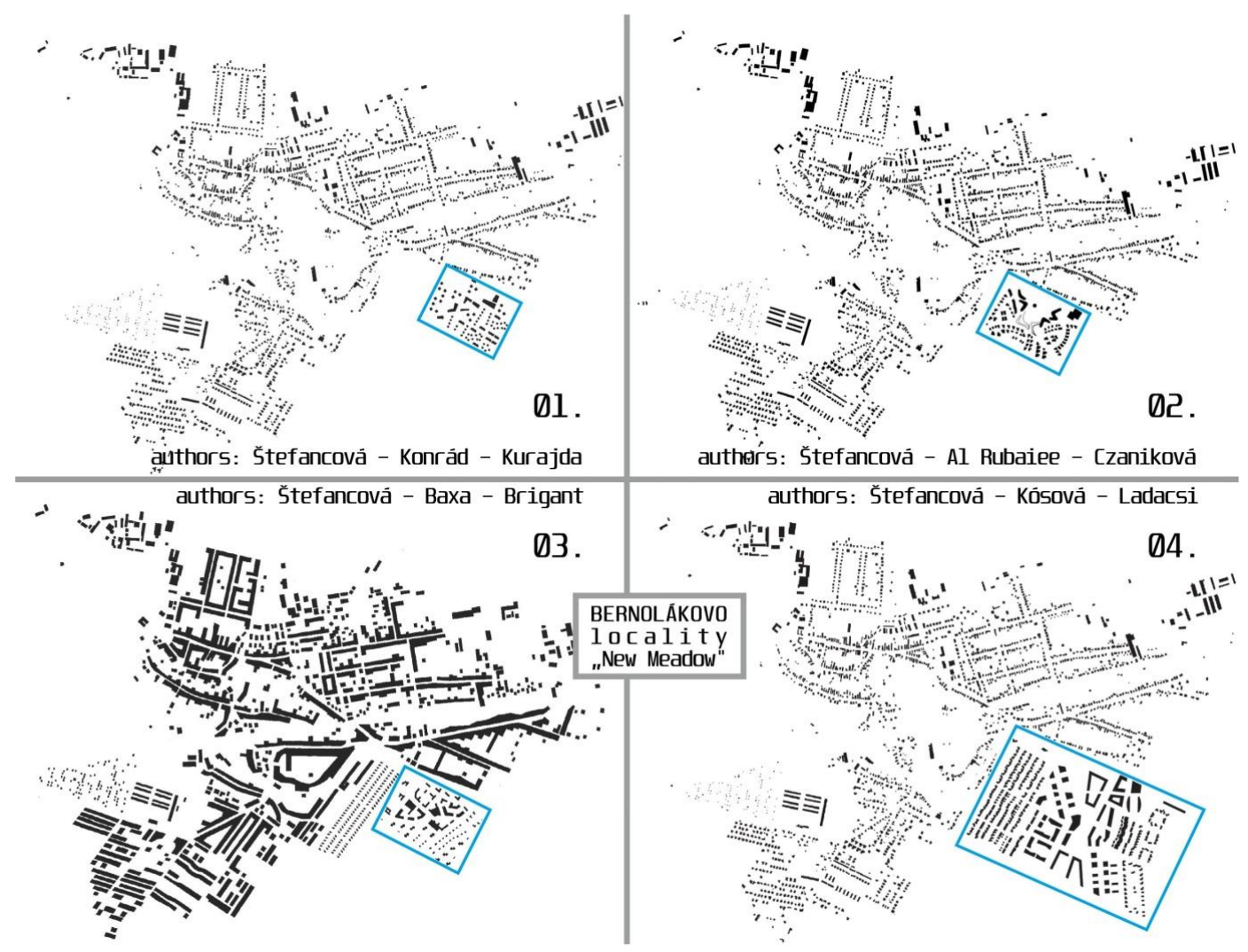

Fig 3. Bernolákovo locality "New Meadow": proposals of the new residential zones. (Authors are shown in the figure.) 


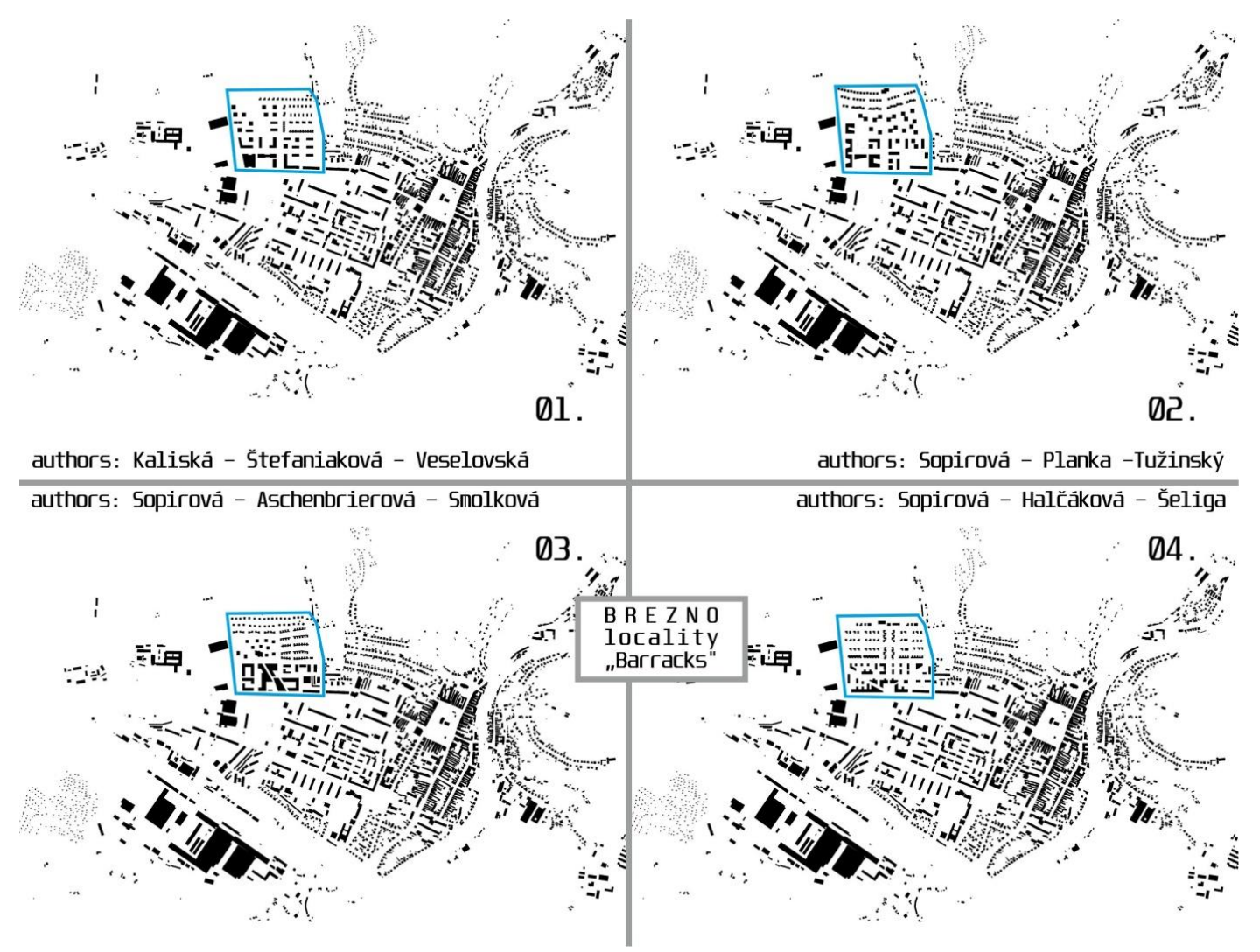

Fig 4. Brezno locality "Barracks": proposals of the new residential zones. (Authors are shown in the figure.)

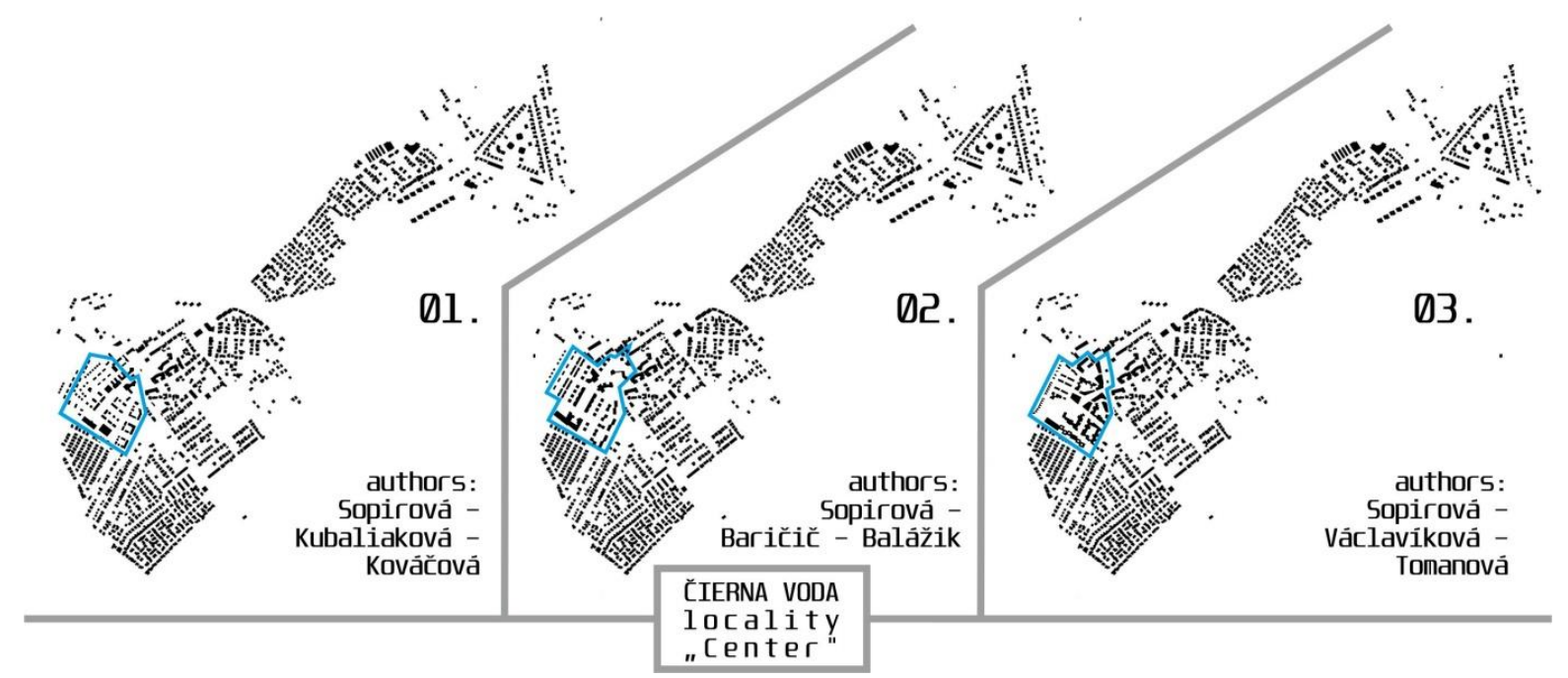

Fig 5. Čierna voda locality "Centre": proposals of the new residential zones. (Authors are shown in the figure.) 


\subsection{Assessment of quantitative and qualitative parameters of the proposed residential zones}

\subsubsection{Quantitative parameters}

Selected settlements represent the sample with different development conditions but in all of them, the intensive development of new residential areas is recorded.

One of the important indicators of the land-use intensity, as well as its viability, is the presence of the population represented by population density, which creates conditions for the development of attractive public spaces of high quality. Assessment of the quantitative parameters of the selected Slovak settlements showed that the population densities of the rural settlements and the small town are relatively low. The population density of selected settlements is in the range from 19.76 p./ha (in Bernolákovo) to 46.95 (in Chorvátsky Grob) (Table 1). In the small town of Brezno (27.46 p./ha), population density is lower than in a suburban village of Chorvátsky Grob. Population densities of Bernolákovo and Brezno are corresponding with the research results of Sopirová (2003), who defines the population density of Slovak rural settlements in the range from $7.5 \mathrm{p}$./ha to $27.5 \mathrm{p}$./ha and the suburban settlements in the range from 8.5 to $33.2 \mathrm{p}$./ha. According to Vitková (2008b), the population densities around 25 p./ha are also typical of American and Australian settlements characterised by developments of single family houses. The suburban settlement of Chorvátsky Grob - Čierna voda with its population density of 46.95 ob./ha stands out from the average, due to the enormous increase of single-family houses development in recent years.

Tab 1. Quantitative and qualitative parameters of the selected settlements.

\begin{tabular}{|c|c|c|c|c|c|c|c|}
\hline 卢 & $\begin{array}{l}\text { Scheme of the } \\
\text { Settlement with an } \\
\text { emphasis on the } \\
\text { center of the newly } \\
\text { proposed site }\end{array}$ & $\begin{array}{l}\text { Cadastral } \\
\text { area / } \\
\text { built-up } \\
\text { area }\end{array}$ & $\begin{array}{l}\text { Population } \\
\text { of the } \\
\text { settlement }\end{array}$ & $\begin{array}{l}\text { Gross } \\
\text { density } \\
\text { of } \\
\text { populati } \\
\text { on }\end{array}$ & $\begin{array}{l}\text { SCR } \\
\text { Site } \\
\text { cover } \\
\text { age } \\
\text { ratio }\end{array}$ & $\begin{array}{l}\text { the } \\
\text { proportion } \\
\text { of green } \\
\text { areas per } \\
\text { person }\end{array}$ & $\begin{array}{l}\text { Identity of } \\
\text { the } \\
\text { settlement } \\
\text { and } \\
\text { prevailing } \\
\text { function }\end{array}$ \\
\hline 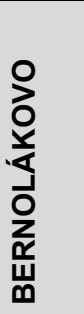 & & $\begin{array}{l}2843 \text { ha/ } \\
\mathbf{3 1 1} \text { ha }\end{array}$ & $\begin{array}{l}\text { 1991: } 4477 \\
\text { 2001: } 4627 \\
\text { 2011: } 5476 \\
\text { 2016: } 6146 \\
+37.20 \%\end{array}$ & $\begin{array}{l}19.76 \\
\text { p./ha }\end{array}$ & 0.10 & $40.48 \mathrm{~m}^{2} / \mathrm{p}$ & $\begin{array}{l}\text { - rural } \\
\text { settlement } \\
\text { in the } \\
\text { agglomerat } \\
\text { ion of the } \\
\text { capital city } \\
\text { - housing }\end{array}$ \\
\hline 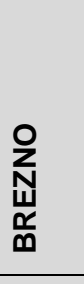 & BAEC & $\begin{array}{l}12946 \mathrm{ha} / \\
\mathbf{7 5 1} \mathrm{ha}\end{array}$ & $\begin{array}{l}\text { 1991: } 22469 \\
\text { 2001: } 22875 \\
\text { 2011: } 21827 \\
\text { 2016: } 20625 \\
-8.21 \%\end{array}$ & $\begin{array}{l}27.46 \\
\text { p./ha }\end{array}$ & 0.40 & $36.41 \mathrm{~m}^{2} / \mathrm{p}$ & $\begin{array}{l}\text { - district } \\
\text { town with } \\
\text { housing } \\
\text { areas of } \\
\text { rural } \\
\text { character }\end{array}$ \\
\hline 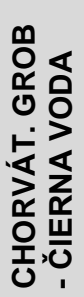 & 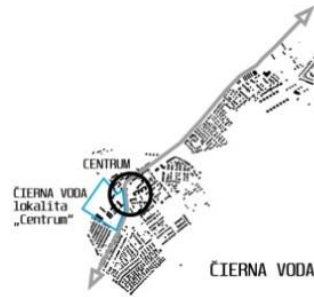 & $\begin{array}{l}1512 \text { ha/ } \\
\mathbf{1 1 3} \text { ha }\end{array}$ & $\begin{array}{l}\text { 1991: } 1571 \\
\text { 2001: } 1587 \\
\text { 2011: } 4105 \\
\text { 2016: } 5315 \\
+238.32 \%\end{array}$ & $\begin{array}{l}46.95 \\
\text { p./ha }\end{array}$ & 0.30 & $19.13 \mathrm{~m}^{2} / \mathrm{p}$ & $\begin{array}{l}\text { - separate } \\
\text { part of the } \\
\text { village } \\
\text { Chorvátsky } \\
\text { Grob } \\
\text { - housing }\end{array}$ \\
\hline
\end{tabular}


Tab 2. Quantitative and qualitative parameters of the proposed residential zones (green colour lines presents recreational public space, grey colour means social space and white means other spaces).

\begin{tabular}{|c|c|c|c|c|c|c|c|c|}
\hline \multirow[b]{2}{*}{$\begin{array}{l}\text { Uు } \\
\text { Oे } \\
\end{array}$} & \multirow[t]{2}{*}{ Proposal } & \multirow[t]{2}{*}{$\begin{array}{l}\text { Area } \\
\text { of the } \\
\text { pro- } \\
\text { posal }\end{array}$} & \multirow[t]{2}{*}{$\begin{array}{l}\text { The } \\
\text { number } \\
\text { of new } \\
\text { residents }\end{array}$} & \multirow{2}{*}{$\begin{array}{l}\text { Gross } \\
\text { popula- } \\
\text { tion } \\
\text { density } \\
\text { (people } \\
\text { per } \\
\text { hectare) }\end{array}$} & \multirow{2}{*}{$\begin{array}{l}\text { SCR } \\
\text { Site } \\
\text { cove } \\
\text { rage } \\
\text { ratio }\end{array}$} & \multirow{2}{*}{$\begin{array}{l}\text { The } \\
\text { proporti } \\
\text { on of } \\
\text { green } \\
\text { areas } \\
\text { per } \\
\text { person }\end{array}$} & \multirow{2}{*}{$\begin{array}{l}\text { The share } \\
\text { of social } \\
\text { (SPS) and } \\
\text { recreatio- } \\
\text { nal } \\
\text { (RPS)......... }\end{array}$} & $\begin{array}{l}\text {....... public spaces } \\
\text { and other open } \\
\text { spaces (OOS) for } \\
\text { total space }\end{array}$ \\
\hline & & & & & & & & $\begin{array}{l}\text { Key features of the } \\
\text { proposal }\end{array}$ \\
\hline \multirow{4}{*}{ 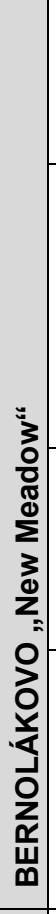 } & & $\begin{array}{l}19.80 \\
\text { ha }\end{array}$ & 980 & 50 p./ha & 0.08 & $\begin{array}{l}90.92 \\
\mathrm{~m}^{2} / \mathrm{p} .\end{array}$ & $\begin{array}{l}5 \% \text { SPS } \\
30 \% \text { RPS } \\
65 \% \text { OOS }\end{array}$ & $\begin{array}{l}\text { - central square } \\
\text { - markets } \bullet \text { sports } \\
\text { fields along the river } \\
\text { with the shipyard }\end{array}$ \\
\hline & 8 & $\begin{array}{l}180.0 \\
0 \text { ha }\end{array}$ & 1200 & 67 p./ha & 0.12 & $60 \mathrm{~m}^{2} / \mathrm{p}$ & $\begin{array}{l}5 \% \text { SPS } \\
45 \% \text { RPS } \\
50 \% \text { OOS }\end{array}$ & $\begin{array}{l}\text { - the main } \\
\text { recreational zone of } \\
\text { the village } \\
\text { - gateway to the } \\
\text { centre } \\
\text { - overpasses, } \\
\text { footbridges }\end{array}$ \\
\hline & 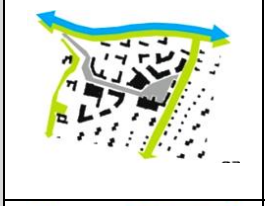 & $\begin{array}{l}19.90 \\
\text { ha }\end{array}$ & 1846 & 93 p./ha & 0.16 & $\begin{array}{l}39.89 \\
\mathrm{~m}^{2} / \mathrm{p}\end{array}$ & $\begin{array}{l}20 \% \text { SPS } \\
20 \% \text { RPS } \\
60 \% \text { OOS }\end{array}$ & $\begin{array}{l}\text { - social public spaces } \\
\text { as the meeting places } \\
\text { - recreational trails } \\
\text { as a form of } \\
\text { pedestrian movement }\end{array}$ \\
\hline & $m$ & $\begin{array}{l}25.00 \\
\text { ha }\end{array}$ & 2560 & 102 p./ha & 0.21 & $\begin{array}{l}34.18 \\
\mathrm{~m}^{2} / \mathrm{p}\end{array}$ & $\begin{array}{l}55 \% \text { SPS } \\
15 \% \text { RPS } \\
30 \% \text { OOS }\end{array}$ & $\begin{array}{l}- \text { new community } \\
\text { centre } \bullet \text { urban } \\
\text { character of public } \\
\text { spaces } \bullet \text { connection } \\
\text { of the bike trails and } \\
\text { the resting areas }\end{array}$ \\
\hline \multirow{4}{*}{ 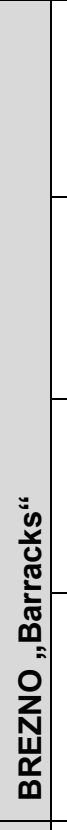 } & $:$ & $\begin{array}{l}13.50 \\
\text { ha }\end{array}$ & 1282 & 95 p./ha & 0.17 & $\begin{array}{l}42.12 \\
\mathrm{~m}^{2} / \mathrm{p}\end{array}$ & $\begin{array}{l}7 \% \text { SPS } \\
29 \% \text { RPS } \\
64 \% \text { OOS }\end{array}$ & $\begin{array}{l}\text { - creation of a } \\
\text { "green" public spaces } \\
\text { - more amenities } \bullet \\
\text { visual use of technical } \\
\text { infrastructure }\end{array}$ \\
\hline & & $\begin{array}{l}13.40 \\
\text { ha }\end{array}$ & 1380 & 103 p./ha & 0.18 & $\begin{array}{l}64.09 \\
\mathrm{~m}^{2} / \mathrm{p} .\end{array}$ & $\begin{array}{l}9 \% \text { SPS } \\
40 \% \text { RPS } \\
51 \% \text { OOS }\end{array}$ & $\begin{array}{l}\text { - New spaces for } \\
\text { various events } \\
\text { - hierarchy of public } \\
\text { spaces } \bullet \text { quality of } \\
\text { life at any age }\end{array}$ \\
\hline & 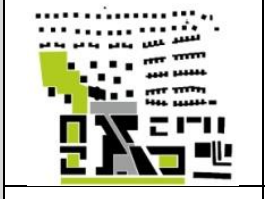 & $\begin{array}{l}13.60 \\
\text { ha }\end{array}$ & 1608 & 118 p./ha & 0.19 & $\begin{array}{l}51.59 \\
\mathrm{~m}^{2} / \mathrm{p} .\end{array}$ & $\begin{array}{l}15 \% \text { SPS } \\
20 \% \text { RPS } \\
65 \% \text { OOS }\end{array}$ & $\begin{array}{l}\text { - superiority of } \\
\text { pedestrians } \bullet \text { leisure } \\
\text { activities } \bullet \text { culture - } \\
\text { cinema, theatre plays, } \\
\text { parties, conferences }\end{array}$ \\
\hline & 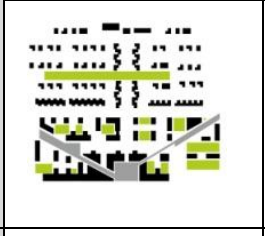 & $\begin{array}{l}13.50 \\
\text { ha }\end{array}$ & 1126 & $85 \mathrm{p} . / \mathrm{ha}$ & 0.16 & $\begin{array}{l}45.56 \\
\mathrm{~m}^{2} / \mathrm{p} .\end{array}$ & $\begin{array}{l}20 \% \text { SPS } \\
15 \% \text { RVP } \\
65 \% \text { OOS }\end{array}$ & $\begin{array}{l}\text { - compact urban } \\
\text { structure } \bullet \text { new public } \\
\text { spaces with } \\
\text { observation tower } \bullet \\
\text { human scale of public } \\
\text { spaces }\end{array}$ \\
\hline 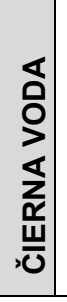 & 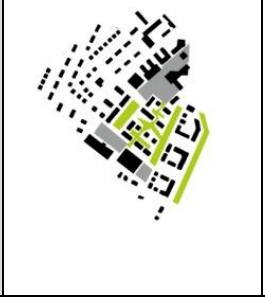 & $\begin{array}{l}13.30 \\
\text { ha }\end{array}$ & 750 & 56 p./ha & 0.22 & $\begin{array}{l}72.71 \\
\mathrm{~m}^{2} / \mathrm{p}\end{array}$ & $\begin{array}{l}20 \% \text { SPS } \\
20 \% \text { RPS } \\
60 \% \text { OOS }\end{array}$ & $\begin{array}{l}\text { - new centre } \bullet \\
\text { addition of bike routes } \\
\bullet \text { central square } \\
\text { surrounded by public } \\
\text { space } \bullet \text { new } \\
\text { functions like social } \\
\text { services and } \\
\text { business zone }\end{array}$ \\
\hline
\end{tabular}




\begin{tabular}{|l|l|l|l|l|l|l|l|}
\hline & $\begin{array}{l}13.63 \\
\text { ha }\end{array}$ & 891 & $65 \mathrm{p} . / \mathrm{ha}$ & 0.33 & $\begin{array}{l}59.66 \\
\mathrm{~m}^{2} / \mathrm{p} .\end{array}$ & $\begin{array}{l}\mathbf{3 0 \%} \mathrm{SPS} \\
\mathbf{2 0 \%} \mathrm{RPS} \\
50 \% \text { OOS }\end{array}$ & $\begin{array}{l}\bullet \text { connection of social } \\
\text { public spaces } \\
\text { slowing down of } \\
\text { traffic on square } \\
\text { overpasses for } \\
\text { pedestrians }\end{array}$ \\
\hline
\end{tabular}

Comparing the assessed population densities of selected settlements (19.76 - $46.95 \mathrm{p} . / \mathrm{ha})$ and the population densities of the newly proposed residential zones $(50-118 \mathrm{p} . / \mathrm{ha})$, it is clear that the population densities of the proposals, even if they were located in the periphery, are much higher than the population densities of the settlements (Figure 6). In general, it can be said that the main difference in the population densities between the settlement and the proposals have been traced in Brezno, which reflects the hierarchy of the selected settlements.
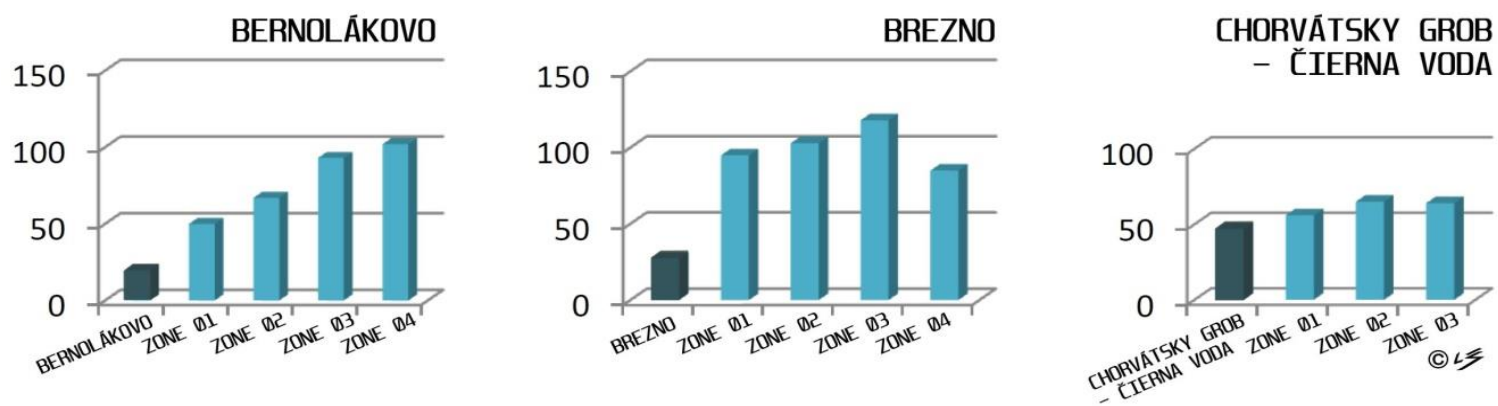

Fig 6. Comparison of the population densities of the built-up area of the selected settlements with population densities of the individual proposals of residential zones.

All of the newly proposed residential zones had population densities higher than 10-30 p./ha, which Hnilička (2012) considers as typical densities in peripheral (suburban) areas, which means that in this respect, they are more efficient. All proposed residential zones also exceeded the population density 50 p./ha (Table 2), which is, according to Newman - Kenworthy (1989), the minimum threshold for the operation of public transport. Six proposals even reached the population density higher than 80 p./ha, that is, according to Hnilička (2012), already the value supports walking. This also supports usability of proposed public spaces and the hierarchical structure of the residential zone.

The relatively high differences in population densities of the proposals are the result of their variability. Nevertheless, it is clear that the population densities of the proposals are higher than settlements average and the values typical of the current residential development in rural areas.

The following examined quantitative parameter important for the assessment of efficiency was the site coverage ratio (SCR). Master plans of the selected settlements set the optimal values of SCR as 0.1 (Bernolákovo - Kost'ál, Kostálová, 1995), 0.3 (Chorvátsky Grob - Čierna voda Chudík et. al., 2013) and 0.4 (Brezno - Valková et. al., 2007). The values of SCR in examined proposals are varying in range from 0.08 to 0.35 which is approximately comparable with recommendations of master plans.

Similar values of SCR in such kinds of development are set also by the current researchers. Kohout et al. (2016) figured out that the SCR in the outskirts of Prague - Praha Nebušice is 0.17. Koucký et al. (2014), assessing the selected segments of Prague, defined the characteristic SCR for suburb $(S C R=0.18)$ and periphery $(S C R=0.16)$. Vitková $(2008)$ mentioned the SCR in individual zones of European cities: a residential zone with single-family houses $\mathrm{SCR}=0.2$; residential zone with intensive development SCR $=0.4$. Prinz (1991) set the SCR for 
the development of single-family houses $(S C R=0.17)$, courtyard houses $(S C R=0.4)$ and row houses $(\mathrm{SCR}=0.58)$.

The SCR of examined residential zones corresponded with above-mentioned values. The important thing is the fact that also the residential houses (which are generally more efficient at equal value of SCR than single-family houses) were proposed on a larger scale. It means that the proposals are at least as efficient as the current development or even more.

Seeing the growing population and the increasing value of SCR, the proportion of the green area is decreasing, the proportion of green areas per person was studied. Komrska (2008) set the normative for greenery in the city to 8 to $12 \mathrm{~m}^{2}$ per person. The proportion of green areas per person in selected settlements varied from $19.13 \mathrm{~m}^{2} / \mathrm{p}$. (Čierna voda) through $36.41 \mathrm{~m}^{2} / \mathrm{p}$. (Brezno) and to $40.48 \mathrm{~m}^{2} / \mathrm{p}$. (Bernolákovo). Based on the Melcerová, Kollár (2012) assessing the new developments in Záhorská Bystrica, a city district of Bratislava with rural character, was the proportion of green areas per person in such development set in the range of $17.5 \mathrm{~m}^{2} / \mathrm{p}$. to $19.6 \mathrm{~m}^{2} / \mathrm{p}$. The proportion of green areas per person in examined proposals varying from $34.18 \mathrm{~m}^{2} / \mathrm{p}$. to $90.92 \mathrm{~m}^{2} / \mathrm{p}$., is considerably more favourable (Table 3). Differences between proposals result from a specific location within the settlement and surrounding natural conditions.

Tab 3. The share of social (SPS) and recreational (RPS) public spaces and other open spaces (OOS) for undeveloped space.

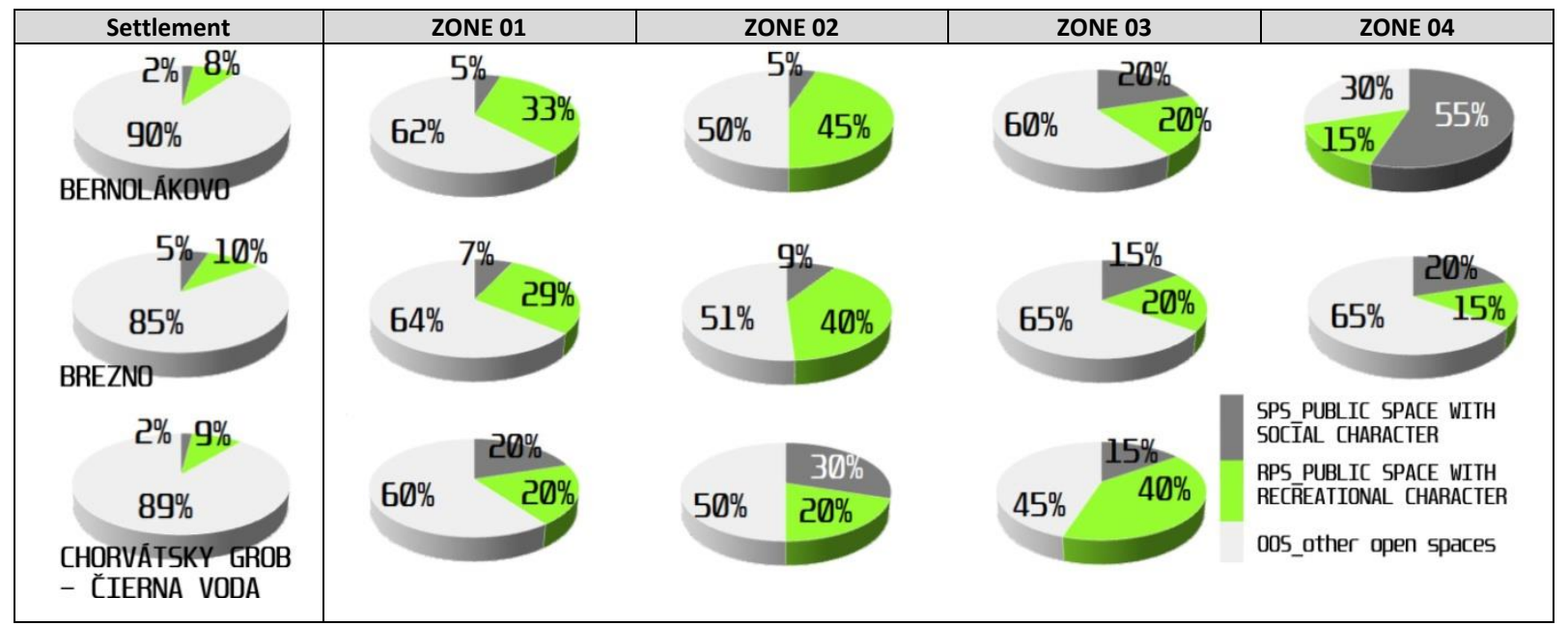

The last quantitative assessment was focused on the share of social (SPS) and recreational (RPS) public spaces and other open spaces (OOS) for total open space of the examined zones and settlements. The result of comparing the percentage of social public spaces (SPS), recreational public spaces (RPS) and other open spaces (OOS) of the total open space of the individual zones shows the diverse percentage of SPS and RPS (Table 4), depending on the nature of the proposal. The percentage of RPS in zones (8-45\%) as well as in the whole settlements (8-10\%), was almost always significantly higher than the percentage of SPS in zones $(5-30 \%)$ and in the whole settlements $(2-5 \%)$. The percentage of SPS together with RPS in examined residential zones, was in the range of $35-55 \%$.

Koucký et al. (2014) defined the percentage of public spaces of residential zones on the periphery of Prague in the range of 17-29\%. According to Kohout et al. (2016), the percentage of public spaces in Praha - Nebušice representing the development of single-family houses at the periphery is $23 \%$. Above-mentioned percentages are markedly below the percentages in examined proposals. While examined proposals focused on the design of social and recreational public spaces, the standard residential developments of single-family houses do not pay attention to public spaces, which is usually represented only by the necessary traffic-operational spaces. 


\subsubsection{Qualitative parameters}

The diversity of the social and recreational public spaces in individual proposals is demonstrated by their varying percentages, as well as functional and hierarchical variations of the local centres. The importance of the hierarchy of built-up area, particularly the hierarchy of squares and streets in relation to the original settlement, was demonstrated in all of the proposals.

Bernolákovo - New Meadow: Public spaces were designed in contact to the square, functionally focused on amenities, markets, recreational background facilities of shipyards and public greenery, with pedestrian and bicycle routes with resting areas (Figure 7). The character of the proposed developments is between rural and urban which is in line with the location of Bernolákovo as the suburb of Bratislava and its characteristic surroundings with greenery and watercourse.
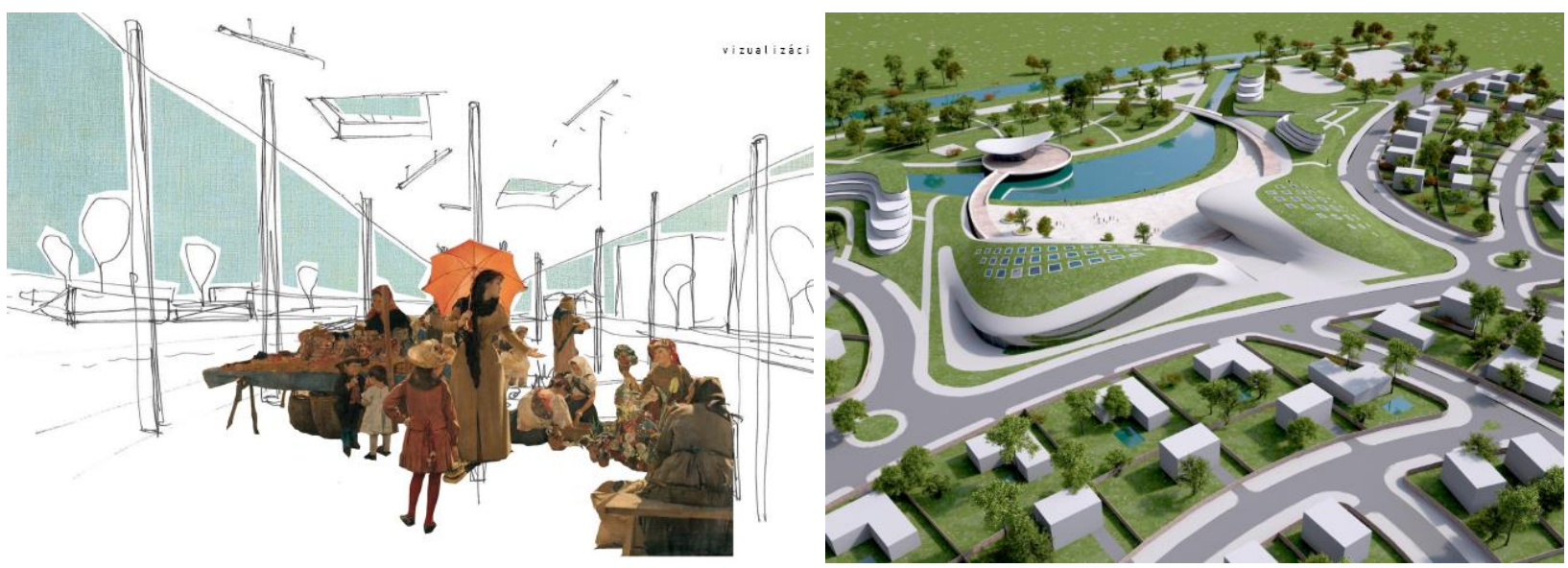

Fig 7. Variant concepts of newly proposed residential zones in Bernolákovo. Left figure: authors Konrád, Kurajda, Štefancová. Right figure: authors Al Rubaiee, Czaniková, Štefancová.

Brezno - Barracks: The public spaces in this brownfield were designed with the emphases on the pedestrian connection of the newly proposed residential zone and the town centre. The proposed square with amenities and observation has an urban character (Figure 8). The urban structure is compact. Recreation in geometrically designed greenery offers various activities for all generations. Pedestrian routing leads to the local node and clearly heads towards the town centre. The overall character of the proposed residential zone is between rural and urban. Proposals combine the advantages of quiet family and apartment housing with a lot of greenery and the urban area with various amenities. The geometrical form of the newly proposed urban structure reminds the footprint of the ground plan of former barracks.
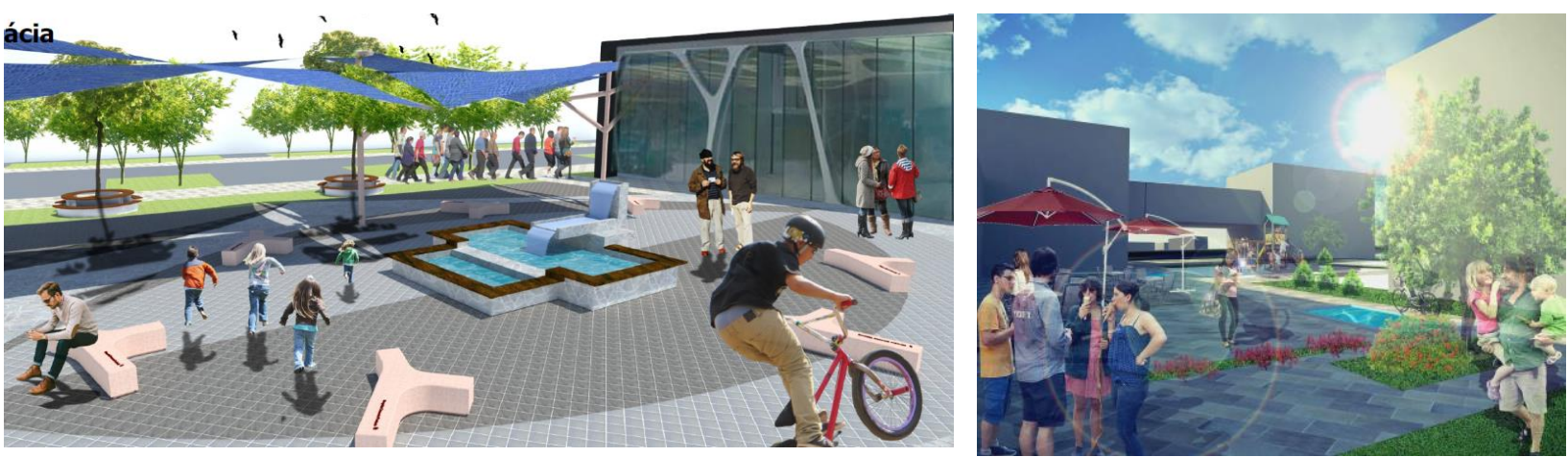

Fig 8. Different approaches in the design of public spaces in Brezno. Left figure: authors Úradník, Sopirová. Right figure: authors Kupčoková, Kamenská, Kaliská. 
Čierna Voda - Centre: Proposals were focused on the creation of a new local square. The necessity to support the existing urban structure by the new square was the condition of achievement of complexity and quality of the newly proposed residential zones in this kind of settlements. The proposed square bounded by compact blocks brings together amenities, social services, business zone and recreational public spaces and creates the clear identity of the neighbourhood (Figure 9. Semi-public courtyards, pedestrian and cycling routes complement the main public space. The character of the residential development in the zone is generally rather rural, offering high quality of housing with good access to Bratislava.
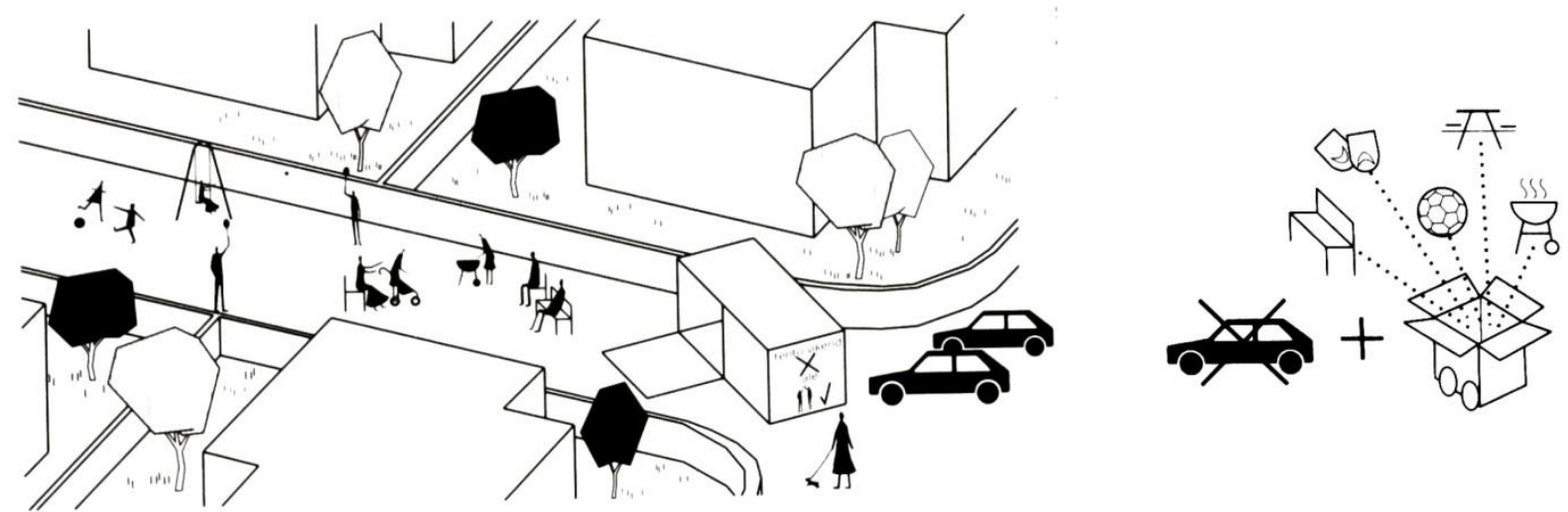

Fig 9. Social public space in the centre of Čierna Voda supports the inhabitants by local facilities. Authors Václavíková, Tomanová, Sopirová.

\section{Conclusion}

The current motto of developers is "more for less", which means high profit and less quality (featuring lower population density, lower efficiency of the built-up area and worse living environment). Assessment of the experimental proposals showed that the efficiency, economy and quality of the residential zone correspond with a wide application of public spaces and public greenery. The proposed residential zones are variously linked to the original spatial urban structure of the settlement to acquire identity and at the same time preserve and support the specificity of the site (genius loci). Based on the studies presented in theoretical part of the research, it can be said that proposed urban structures would have a positive influence on socialisation, community building, mobilisation of the population and the associated vitality of urban structures.

The main findings based on the assessment of quantitative and qualitative parameters of the proposed residential zones were:

1) The population density in the proposed residential zones reached higher values than is the average of the current developments.

2) The proposed building density of the examined residential zones (defined by site coverage ratio - SCR) is comparable with the SCR of the current developments.

3) The share of green areas per person in the proposed residential zones is above standard on average it exceeds several times the recommended values of greenery per person.

4) The share of social and recreational public spaces is more favourable than in current developments, dominated by traffic areas and private space.

5) Wide functional use of the proposed social and recreational public spaces and their spatial coherence with the existing urban structure of the settlement ensures the viability and sustainability of the proposed residential zones.

The research confirmed that the efficient development of residential zone can be reached even with a higher proportion of public spaces, recreation and greenery. This allows providing better living conditions for residents. 
[1] Bašová, S. (2016). Impulzy pre prít’ažlivé póly stretnutia. Czech Journal of Civil Engineering 2(1), 14-19.

[2] Choumert, J. (2010). An empirical investigation of public choices for green spaces. Land Use Policy 27(4), 1123-1131. DOI: 10.1016/j.landusepol.2010.03.001.

[3] Czafík, M. \& Tóthová, Z. (2016). Percepcia suburbanizačného procesu v pohraničnom regióne Bratislavy a jeho potenciál. Czech Journal of Civil Engineering 2(2), 27-35.

[4] Gehl, J. (2012). Města pro lidi. Brno: Partnerství.

[5] Heffner, K. (2016). Obszary wiejskie i małe miasta: czy lokalne centra są potrzebne współczesnej wsi? Studia Ekonomiczne. Zeszyty Naukowe Uniwersytetu Ekonomicznego w Katowicach 279, 11-24.

[6] Hnilička, P. (2012). Sídelní kaše. Brno: Host.

[7] Hnilička, P. (2005). Sídelní Kaše - otázky k suburbánni výstavbě rodinných domů. Brno: ERA group, s.r.o.

[8] Hruška, E. (1985). K tvorbe urbanistického prostredia. Bratislava: Zväz slovenských architektov.

[9] Kohout, M., Tichý, D., Tittl, F., Kubánková, J. \& Doležalová, Š. (2016). Sídlište jak dál? Praha: ČVUT.

[10] Komrska, J. (2008). Hladanie optimálneho pomeru zelene v urbanistickej štruktúre príspevok projektu Ecocity. In: Vitková, L., ed., Kvantitatívne parametre urbanistických štruktúr (pp. 50-56). Bratislava: STU.

[11] Kováč, B. (2016). Urbanistické kontexty stavebnej kultúry. Urbanita 28(3-4), 60-63.

[12] Krumpolcová, M. et. al. (2009). Štandardy minimálnej vybavenosti obcí. Bratislava: Urbion.

[13] Geoghegan, J. (2002). The value of open spaces in residential land use. Land Use Policy 19(1), 91-98. DOI: 10.1016/S0264-8377(01)00040-0.

[14] Glaeser, E. L. \& Kahn, M. E. (2004). Sprawl and urban growth. In Vernon Henderson, V. \& Thisse, J.-F., eds., Handbook of regional and urban economics (pp. 2481-2527). DOI: 10.1016/S1574-0080(04)80013-0.

[15] Jarábková, J., Majstríková, L'. \& Kozolka, T. (2016). Financial supporting tools of rural tourism development in Nitra self-governing Region. European Countryside 8(2), 123-134. DOI: 10.1515/euco-2016-0010.

[16] Maas, J., Verheij, R. A., Groenewegen, P. P., de Vries, S. \& Spreeuwenberg, P. (2006). Green space, urbanity, and health: how strong is the relation? Journal of Epidemiology and Community Health 60(7), 587-592. DOI: 10.1136/jech.2005.043125.

[17] McConnell, V. \& Walls, M. (2005). The Value of Open Space: Evidence from Studies of Nonmarket Benefits. Washington DC: Resources for Future.

[18] McCormack, J. (2002). Children's understandings of rurality: exploring the interrelationship between experience and understanding. In Journal of Rural Studies. 18(2), 193-194. DOI: 10.1016/S0743-0167(01)00043-2.

[19] Melcerová, O. \& Kollár, M. (2012). Uplatnenie polyfunkčnosti pri riešení negatívnych dopadov reyidenčnej suburbanizácie v rámci územia vonkajšieho mesta. In: Vitková, L'. \& Kováč, B., eds., Intenzita využitia územia slovenských sídiel (pp. 53-86). Bratislava: STU.

[20] Newman, P. \& Kenworhty, J. (1989). Cities and automobile dependence. Farnham: Gower.

[21] Pospěch, P., Spešná, D. \& Staveník, A. (2015). Images of a good village: a visual analysis of the rural idyll in the "village of the year" competition in the Czech Republic. European Countryside, 7(2), 81-82. DOI: 10.1515/euco-2015-0005. 
[22] Prinz, D. (1991). Städtebau. Stuttgart: Kohlhammer.

[23] Sopirová, A. (2003). Súčasnost' a trendy urbanistického rozvoja vidieckych sídiel na Slovensku [habilitation thesis]. Bratislava: Slovak University of Technology.

[24] Sopirová, A. (2011). Rezidenčná suburbanizácia a jej odraz vo vidieckych obciach ležiacich v zázemí mesta Bratislavy. In Člověk, stavba a územní plánovaní 5 (pp. 57-65). Praha: Czech University of Technology.

[25] Štefancová, L. (2016). Metódy prístupu pri navrhovaní nových verejných priestorov vo vidieckych sídlach - prípadová štúdia Bernolákovo. In Czech Journal of Civil Engineering 2(1), 108-114.

[26] Štěpánková, R. \& Kristiánová, K. (2012). Verejné priestory v urbanistickej štruktúre vidieckych rezidenčných suburbií Bratislavy. In Člověk, stavba a územní plánování 6 (pp. 178-182). Praha: Czech University of Technology.

[27] Vitková, L'. (2015). Baulich-räumliche Entwicklung im Grenzraum von Bratislava von 1990 bis zur Gegenwart. In Kappeler, V. \& Huemer, J, eds., Aktuelle und zukünftige Wohnbauentwicklung im Grenzgebiet Nordburgenland (pp. 83-93). Wien: Institut für Stadtund Regionalforschung der Österreichischen Akademie der Wissenschaften.

[28] Vitková, L'. (2008a). Porovnanie ukazovatel’ov intenzity využitia územia pre rôzne funkčné využitie. In Vitková, L'. et. al. Kvantitatívne parametre urbanistických štruktúr (pp. 27-36). Bratislava: Slovak University of Technology.

[29] Vitková, L'. (2008b). Posúdenie používaných urbanistických ukazovatelov intenzity využitia územia $v$ závislosti od polohy. In Vitková, L'. et. al. (2008). Kvantitatívne parametre urbanistických štruktúr (pp. 17-26). Bratislava: Slovak University of Technology.

[30] Wells, M. \& Evans, G. W. (2003). Nearby Nature: A Buffer of Life Stress among Rural Children. Environment and Behavior. 35(3), 311-330. DOI: $10.1177 / 0013916503035003001$.

Other Sources

[31] Chudík, M., Adamczak, M., Horáková, K. et. al. (2013). Územný plán obce Chorvátsky Grob - zmeny a doplnky. Bratislava: Aurex.

[32] Koucký, R. et. al. (2014). Metropolitní plán. Praha: IPR, s. 543-596.

[33] Kostál, J., Kostálová, A. (1995). Územný plán Bernolákovo v znení neskorších zmien a doplnkov.

[34] Valková, M. et. al. (2007). Územný plán mesta Brezno. 